\title{
Central Bank Digital Currency: One, Two or None?
}

\author{
Christian Pfister ${ }^{1}$ \\ October 2019, WP \# 732
}

\begin{abstract}
This paper considers the motives, modalities, and possible consequences of central bank digital currency (CBDC) issuance. It starts by drawing a distinction between a wholesale CBDC (WCBDC), accessible only to financial intermediaries, and a retail CBDC (RCBDC), accessible to the general public. The issuance of one could be dissociated from the other, implying the possibility of one, two, or no CBDC(s). The main motive for issuing a WCBDC could be to promote financial innovation and to lower transactions costs using a blockchain. The motives for issuing a RCBDC could be to supply the public with a digitalised monetary instrument without any liquidity or credit risks, easy to access and cheap to use. A CBDC would be created or destroyed only by the central bank and would be issued and exchanged at par with other forms of central bank money (banknotes and reserves). A WCBDC would have to be issued on a permissioned rather than a public blockchain. It would also have to be remunerated to keep reserves and the WCBDC at par. A RCBDC would not necessarily use the blockchain and would most likely involve intermediaries. The issuance of a CBDC would represent a supply shock, which would support economic growth in the medium to long run and could transitorily weigh on prices. One consequence of issuing a WCBDC could be the development of an intraday market, which could in turn lead to the adoption of a real-time monetary policy. Furthermore, the issuance of a RCBDC could put a floor to bank deposit rates and, if it is remunerated, raise them. If the RCBDC were not remunerated, the effective lower bound would be raised to zero and the effectiveness of asset purchases by the central bank could be diminished. If it were, the interest and exchange rate channels should be strengthened. The remuneration of the RCBDC would thus seem to create a trade-off between the effectiveness of monetary policy and the cost of bank intermediation.
\end{abstract}

Keywords: Central Bank, Currency, Digitalisation, Financial Stability, Monetary Policy. JEL classification: E40, E42, E52, E58:

\footnotetext{
1 Banque de France, Adviser to the Governor, Paris 1 Panthéon Sorbonne and Sciences Po, christian.pfister@banque-france.fr. The views expressed are mine and do not necessarily reflect those of the Banque de France, the Eurosystem, Paris 1 Panthéon Sorbonne or Sciences Po. I would like to thank Adeline Bachellerie, Françoise Drumetz, Jean-Michel Godeffroy, Julien Lasalle, Andrés Lopez-Vernaza, Anastasia Melachrinos, Lionel Potier, Mariana Rojas-Breu and Nicolas de Sèze for their remarks and remain solely responsible for any error.
} 


\section{NON-TECHNICAL SUMMARY}

This paper considers the motives, modalities, and possible consequences of central bank digital currency (CBDC) issuance. It draws a distinction between a wholesale CBDC (WCBDC) and a retail CBDC (RCBDC). A WCBDC would be accessible only to financial intermediaries, while a RCBDC would be accessible to the general public, including financial intermediaries. As the issuance of one sort of CBDC could be dissociated from the other, there could thus be one, two, or no CBDC(s).

One motive for issuing a WCBDC could be to promote financial innovation and to lower transactions costs using a blockchain. As the underlying technology (the Distributed Ledger Technology - DLT) does not involve high costs, the issuance of a WCBDC could also improve the contestability of the financial services industry by supporting competition through the entry of new providers. The motives for issuing a RCBDC may vary from one economy to the other, even though the general objective would be to supply the public with a digitalised monetary instrument without any liquidity or credit risks, easy to access and cheap to use. A step towards more complete markets would thus be taken, leading to an improvement in social welfare, and breaking the current incompatibility triangle between universal access, security and digitalisation of liquid financial assets (see Chart).

\section{Current supply of liquid financial assets}

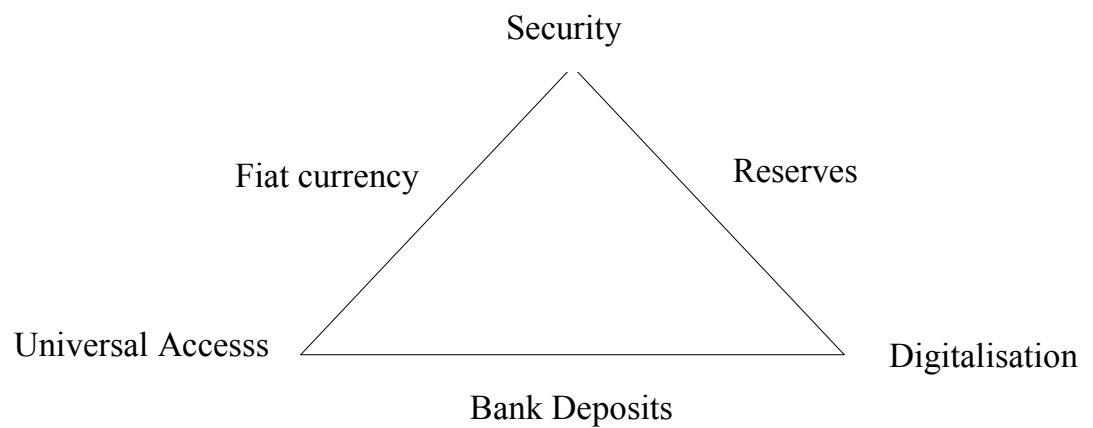

A CBDC, be it a wholesale or a retail one, should feature a number of characteristics. The first characteristic of a CBDC would be that it could be created or destroyed only by the central bank. Furthermore, in order not to break the uniformity of the payment system, it would be issued and exchanged at par with the other forms of central bank money (banknotes and reserves), thus making it possible to keep the fungibility of the monetary base. This implies that its supply should be perfectly elastic. In order to maintain the WCBDC and the RCBDC separate and to keep some information confidential, the WCBDC would have to be issued on a permissioned blockchain, not a public one. As reserves are remunerated, it seems unavoidable to also remunerate the WCBDC, in order to keep reserves and the WCBDC at par. Most central banks lack a direct experience in managing individuals' accounts, and would not take the reputational risk of a RCBDC being used in fraudulent transactions. Moreover, there would a priori be little interest in having the users validate transactions. A RCBDC would thus not necessarily be issued on a blockchain, while its circulation would most likely involve intermediaries. Whether nonresidents should be allowed to hold a CBDC is an open question, although it would seem difficult to prevent them from doing so in the case of a RCBDC.

By increasing competition and allowing productivity gains, both in payment services and beyond (financial services, retail industry, etc.), the issuance of a CBDC would represent a supply shock, which would support economic growth in the medium to long run and would transitorily weigh on prices. As a WCBDC would be accessible universally and $24 \times 7 \times 365$, its users would make 
transactions when financial markets and central banks are usually closed; one consequence could be the development of an intraday market for the WCBDC, which could in turn lead to the adoption of a real-time monetary policy. Also, the issuance of a RCBDC could put a floor to bank deposit rates and, if it is remunerated, raise them.

The interest rate on required reserves could be used for the remuneration of the WCBDC, for reasons of simplicity and efficiency. As regards the RCBDC, a rate below or equal to the rate of remuneration of excess reserves could be applied to it, in order to dissuade institutions from holding the RCBDC and thus keep it for the public. If the RCBDC were not remunerated, the effective lower bound would be raised to zero and the effectiveness of asset purchases by the central bank could be diminished. If it were, the interest and exchange rate channels should be strengthened and the cost of banks' resources should increase. The remuneration of the RCBDC would thus create a trade-off between the effectiveness of monetary policy and the cost of bank intermediation.

Concerns have been voiced that the issuance of a RCBDC may facilitate bank runs and exacerbate liquidity strains. However, even if runs became more frequent, their negative consequences for economic activity would likely be lessened, since the main motivation for supplying a CBDC is to allow all economic agents to have a perfectly safe digitalised means of payment at their disposal, and thus to preserve economic activity in all circumstances. This motive would particularly be at play in times of crisis.

\section{Monnaie digitale de banque centrale : une, deux ou aucune?}

\section{RÉSUMÉ}

Ce papier s'interroge sur les motifs, les modalités et les conséquences de l'émission d'une monnaie digitale de banque centrale (MDBC). Il commence par établir une distinction entre MDBC de gros (MDBCG), accessible aux seuls intermédiaires financiers, et MDDBC de détail (MDBCD), accessible à l'ensemble du public. Les deux émissions étant dissociables, il pourrait y avoir une, deux ou aucune MDBC. Le motif principal d'émission d'une MDBCG pourrait être de promouvoir l'innovation financière et d'abaisser les coûts de transaction grâce à l'utilisation de la Blockchain. Les motifs d'émettre une MDBCD pourraient être de mettre un instrument monétaire dématérialisé, dépourvu de tout risque de liquidité ou de crédit, facile d'accès et peu coûteux à la disposition du public. Une CBDC ne pourrait être émise ou détruite que par la banque centrale et serait émise et échangée au pair avec les autres formes de monnaie centrale (billets et réserves). Une MDBCG devrait être émise sur une blockchain « permissionnée » plutôt que publique. Elle devrait être rémunérée afin de conserver la parité avec les réserves. Une MDBCD n'utiliserait pas forcément la Blockchain mais sa circulation s'effectuerait très probablement par le truchement d'intermédiaires. L'émission d'une MDBC constituerait un choc d'offre qui soutiendrait la croissance à moyen et long terme et pourrait peser transitoirement sur les prix. Une conséquence de l'émission d'une MDBCG pour être la formation d'un marché intra-journalier de cette dernière, pouvant à son tour conduire à l'adoption d'une politique monétaire en temps réel. Par ailleurs, l'émission d'une MDBCD pourrait mettre un plancher aux taux des dépôts bancaires et, si elle est rémunérée, les accroître. Si la MDBCD n'est pas rémunérée, la borne effective des taux d'intérêt à la baisse pourrait être relevée à zéro et l'efficacité des achats d'actifs par la banque centrale se trouver réduite. Si elle l'est, les canaux des taux d'intérêt et du change pourraient être renforcés. La rémunération de la MDBCD serait ainsi à l'origine d'un arbitrage entre l'efficacité de la politique monétaire et le coût de l'intermédiation bancaire. 


\section{Introduction}

According to a survey conducted by the Bank for International Settlements in the course of 2018, to which 63 central banks responded, $70 \%$ of them were then (or planned to be soon) engaged in central bank digital currency (CBDC) work. However, only three of them reported being very likely to issue a CBDC within the next six years (Barontini and Holden, 2019).

This paper looks into the motives, the modalities, and the possible consequences of the issuance of a CBDC.

\section{Motives}

It is useful to draw a distinction between a wholesale CBDC (WCBDC) and a retail CBDC (RCBDC). The first one would be accessible only to financial institutions, while the second one would be accessible to the general public, including financial institutions (Pfister, 2017). As the issuance of one sort of CBDC could be dissociated from the other, there could thus be one, two or no CBDC(s).

\section{Wholesale central bank digital currency}

In public - or "non-permissioned" - blockchains such as Bitcoin, anyone can access transactions, which are conducted under pseudonyms, and participate in the validation "consensus". Public blockchains imply sharing all information and avoid third-party intervention. However, they are both slow and energy-intensive in comparison with modern payment infrastructures. Conversely, in private - or "permissioned" - blockchains, access to information can be limited, and a restricted number of "nodes" can participate in the validation of transactions. This makes it possible to process transactions rapidly at a much lower cost, while preserving the confidentiality of private information. Overall, the use of private blockchains should allow financial institutions to make efficiency gains, particularly in the processing of international transfers and post-market activities. It should also reduce their liquidity needs as well as capital requirements (Pfister, 2017). ${ }^{2}$

However, in order to carry out end-to-end transactions in "tokenised" assets on the blockchain, financial institutions need a liquid and safe asset for making settlements. The creation of stablecoins entirely backed by banking assets, such as J.P. Morgan's JPM Coin (J.P. Morgan, 2019), aims to satisfy this need. This notwithstanding, any private payment instrument presents credit and liquidity risks (i.e. its issuer can default and its supply can be insufficient). Issuing a CBDC would be the only way to allow the circulation of central bank money on a blockchain and would make a perfectly safe and liquid payment instrument available on it (the alternative which would consist in conducting all transactions in the blockchain and then unwinding them on the accounts of the institutions at the central bank for final settlement, would also be possible, but more cumbersome, and would let a credit risk remain in the blockchain). As a result, recourse to the blockchain would become more attractive to financial institutions.

\footnotetext{
${ }^{2}$ In this paper, it is assumed that technological difficulties, such as those relating to scalability, have been dealt with.
} 
Promoting financial innovation and lowering transactions costs through the use of the blockchain could thus be motives for issuing a WCBDC. As the underlying technology (the Distributed Ledger Technology - DLT) does not involve high costs, the issuance of a CBDC could also improve the contestability of the financial services market by supporting competition through the entry of new providers, and thus allow users of financial services to reap more rapidly the benefits of greater efficiency brought about by this technology.

\section{Retail central bank digital currency}

The motives for issuing a RCBDC would be to supply the public with a digitalised monetary instrument without any liquidity or credit risks and easy to access. Indeed, holding digitalised central bank reserves is presently open only to some financial institutions (mainly banks). Furthermore, bank deposits, which are also digitalised, exhibit residual liquidity and credit risks in spite of being insured. Finally, fiat currency, which is accessible to the general public, is not digitalised. As a consequence, issuing a RCBDC would fill a gap in the supply of liquid financial assets. A step towards more complete markets would thus be taken, leading to an improvement in social welfare, and breaking the current incompatibility triangle between universal access, security and digitalisation of liquid financial assets (see Chart). Cash would adjust to the current digitalisation environment (Ingves, 2018), allowing central banks to keep a direct relation with the public in countries where, as in Sweden, the demand for fiat money is decreasing sharply, with a fall by more than half in the initial cash/GDP ratio between 2008 et 2018 , to the benefit of bank deposits. In that regard, since 2016, the Swedish central bank has been studying the possibility of issuing a RCBDC, under the denomination of e-krona (Skingsley, 2016; Sveriges Riksbank, 2017 and 2018). The demand for settling transactions in e-krona is expected to amount to $1 \%$ to $2 \%$ of GDP, or approximately as much as the current demand for cash (Segendorf, 2018). Furthermore, as the supply of e-krona would target a wider public than that currently holding cash - essentially households - whereas in the future wages for instance could be paid in RCBDC, a significant share of this supply would correspond to an additional demand for central bank money (Segendorf, 2018).

\section{Current supply of liquid financial assets}

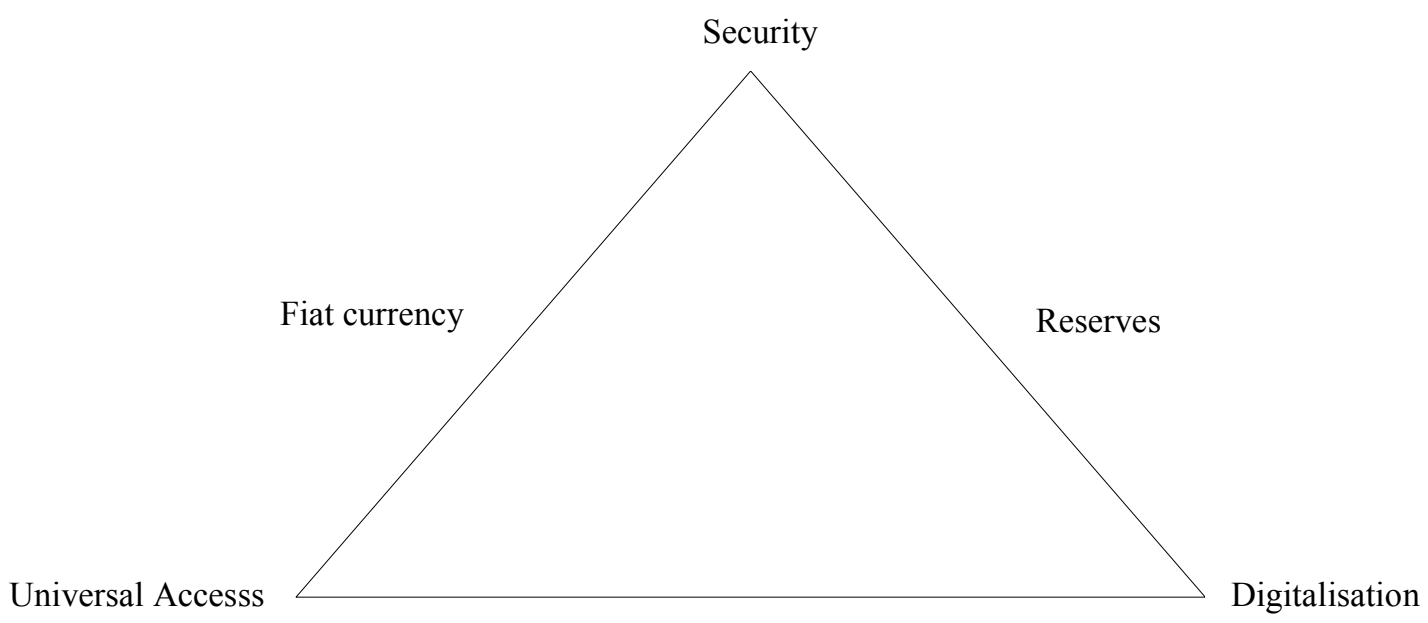

Bank Deposits 
Issuing a RCBDC could also contribute to reducing the social costs of retail payment services (production, issuance, distribution, storage, management, security and destruction costs for central banks, banks, merchants and the public). These costs are estimated at close to $1 \%$ of GDP in the euro area, half of which correspond to the costs of payments in cash (Schmiedel et al., 2012). This cost reduction could principally benefit the most fragile parts of the population, who consume a large amount of payment services, insofar as they would substitute the RCBDC for private money in their payments (Banque de France, 2019). More generally, issuing a RCBDC should support financial inclusion, notably in emerging countries, where the banking system is often loosely present and does not always enjoy public trust. In the same economies, public authorities might be concerned with avoiding that stablecoins targeting the public, such as Libra (Libra Association, 2019) replace the sovereign currencies. However, issuing a RCBDC would not dispense its issuers from supplying a stable currency, so as to preserve its use; for instance, the petro, a cryptocurrency launched in Venezuela in February 2018, does seem to be a success so far. Finally, in an environment of growing digitalisation of retail payments, both the rise in the monetary base and the reduction in costs brought about by issuing a RCBDC would help preserve seigniorage and thus the independence of the central bank in the longer run.

\section{Modalities}

A CBDC, be it a wholesale or a retail one, should feature a number of characteristics. A WCBDC and a RCBDC could also offer specificities one vis-à-vis the other. These specificities would make it possible to dissociate their issuance. They would in particular relate to the targeted public as well as probably the technology and the organisation adopted for their issuance and circulation.

\section{Characteristics of a $C B D C$}

The first characteristic of a CBDC, which would be common to any central bank money, would be that it could be created or destroyed only by the central bank. Furthermore, in order not to break the uniformity of the payment system, it would be issued and exchanged at par with the other forms of central bank money (banknotes and reserves), thus maintaining the fungibility of the monetary base. This implies that its supply should be perfectly elastic. It would thus be difficult to impose constraints on the levels of holdings or to set conversion fees, as such frictions might lead to a breaking of parity between the CBDC and the other forms of central bank money, in particular when the demand for central bank money is high (bank runs, financial crises). Like banknotes and electronic money, but unlike reserves currently, ${ }^{3}$ it should be possible to transact in the CBDC on a $24 \times 7 \times 365$ and peer-to-peer basis.

Two issues need to be addressed. The first one is whether non-residents should be authorised to hold a CBDC, or simply whether it would be technically unfeasible to prevent them from doing so. The second issue is whether, and if so how, the CBDC should be remunerated. These issues are detailed in the following section according to whether they relate to a wholesale or a retail $\mathrm{CBDC}$ (consequences for monetary policy and financial stability are discussed in the following section).

\footnotetext{
${ }^{3}$ However, the Fed considers the possibility of running its real-time gross settlement system (RTGS) 24x7x365 (Federal Reserve System, 2019).
} 


\section{Specificities of a $W C B D C$}

Only financial institutions would be entitled to hold a WCBDC. In order to maintain the WCBDC and RCBDC separate, and to avoid an uncontrolled dissemination of the WCBDC which might result in it being used in illicit transactions, but also to preserve the confidentiality of transactions, it would have to be issued on a permissioned blockchain, to which only financial institutions and the central bank would have access. Unlike reserves, it would thus circulate outside of the central bank books, while remaining traceable by the central bank through the distributed ledger. Unlike other users, the central bank would most likely have to be able to access all information on the blockchain.

As reserves are remunerated, it seems unavoidable to also remunerate the WCBDC, in order to keep reserves and the WCBDC at par.

Besides, should non-resident institutions be authorised to participate in the blockchain accepting the WCBDC? As central banks currently open accounts only to resident institutions (having a branch is sufficient), this would create an unprecedented situation and would probably imply a high degree of international coordination. A positive decision could represent an important factor of internationalisation of the currency, via its use on financial markets, in particular for the first WCBDC-issued reserve currency. A possible drawback could be greater instability in the demand for central bank money (see next section).

Finally, should the blockchain accepting the CBDC be authorised to interact with other blockchains via smart contracts (i.e. computer code enacting contracts automatically when predefined events take place)? In particular, should the WCBDC be authorised to circulate on other blockchains than the issuing one? A negative decision would guard against the risks of uncontrolled dissemination and fraudulent use mentioned above. However, a growing number of financial transactions might then concentrate on the blockchain accepting the WCBDC, creating the risk of "clogging" it, and thus making it less efficient, notably if large international financial institutions were authorised to participate in it.

\section{Specificities of a $\mathrm{RCBDC}$}

As regards banknotes, holding of RCBDC would be open to all economic agents. The central bank would not couple RCBDC issuance with any other supply of financial services, at least at the inception. In particular, the central bank would not supply longer-term savings instruments or any credit to RCBDC holders. Also, as in the case of banknotes, it would seem difficult to prohibit non-residents from holding a RCBDC. In that regard, the Riksbank does not envisage such a prohibition (Sveriges Riksbank, 2017, 2018).

Issuing a monetary asset directly to the public would imply fulfilling regulatory requirements, in particular regarding know-your-customer, anti-money laundering and combating the financing of terrorism obligations. Most central banks lack a direct experience in managing individuals' accounts, and would not take the reputational risk of a RCBDC being used in fraudulent transactions. Moreover, there would a priori be little interest in having users validate transactions. A RCBDC would thus not necessarily be issued on a blockchain, or at least it would not be a 
public one. ${ }^{4}$ In fact, in its simplest form, the RCBDC could just be e-money (Berentsen and Schär, 2018). Furthermore, recourse to intermediaries (banks and payment service providers) would allow the central bank relying on them to implement regulatory obligations.

Several issues arise:

- Should the RCBDC be token-based (also called value-based) or account-based? In the first model, RCBDC transactions would be supported by a physical vector (card, smartphone, etc.). It would be similar to that currently used for banknotes and prepaid cards. In the second model, financial intermediaries would open RCBDC accounts for their customers. This model may lend itself to a more current use of the RCBDC in transactions, if for instance wages were paid in RCBDC;

- Should the RCBDC be legal tender, like cash, so that one could not refuse to receive it for the settlement of a transaction? Being legal tender would certainly support the demand for RCBDC but may not be indispensable;

- How to respond to the public's request for anonymity? It is likely that Parliament would not support a fully anonymous use of a RCBDC. One possibility would be to authorise anonymity only up to a certain amount over a given period, as is currently the case in France for payments in electronic money, although this would create frictions. A more open approach could be that, as is presently the case for card payments, anonymity applies only vis-à-vis the counterparty and thus not vis-à-vis the financial intermediary managing the account or the central bank (Engert and Fung, 2019);

- Should the RCBDC be remunerated? The lack of remuneration would make the RCBDC an e-cash. However, in times of positive interest rates, such a choice may be badly perceived by the public in comparison with the remuneration of reserves held by banks, since the RCBDC can be viewed as "reserves for all" (Niepelt, 2019). Conversely, remunerating the RCBDC, if not in a symbolic manner, would make competition between the central bank and the banking sector for the collection of savings more apparent. It could also increase the public's perception of conflicts of interest (for instance, does the central bank raise its policy rate and thus also the rate of remuneration of the RCBDC - see next section - to fight inflation or to collect more deposits? Pfister, 2017).

\section{Consequences}

A distinction is drawn between consequences for the economy and the financial system, for monetary policy, and for financial stability.

\footnotetext{
${ }^{4}$ The use of a permissioned blockchain, in which only the central bank and/or the banks and payment services providers could validate transactions, could be of interest, with a view to integrating smart contracts, notably for the payment of interest if the RCBDC were remunerated.
} 


\section{Economy and financial system}

By increasing competition and generating productivity gains, both in payment services and beyond (financial services, retail industry, etc.), the issuance of a CBDC would represent a supply shock which would support economic growth in the medium to long run. Moreover, the reduction in the stock of deposits covered by deposit insurance would remove a deadweight loss for the economy since the CBDC would not have to be insured. Finally, the issuance of a RCBDC would support demand by making it possible to carry out transactions, which do not currently take place due to security and privacy concerns, non-monetary costs (time allocation, "shoe-leather costs", etc.), or incurred costs, on-line or at the point of sale (Fung and Halaburda, 2016). Conversely, some potential users of a RCBDC could be unwilling to let the central bank, in charge of guaranteeing privacy but perceived as an administration, have access to their transactions data (Pfister, 2017) and might thus avoid holding a CBDC.

At the international level, the issuance of a CBDC accessible to non-residents by central banks that manage stable currencies could exert a disciplining effect on the monetary policies of their less rigorous partners. Furthermore, if financial assets are issued in CBDC and international investors favour them in their asset allocation, in particular in times of financial crisis, when safety is most sought after, this could result in a higher volatility of the exchange rate (Armelius et al., 2018).

As regards the financial consequences of the two sorts of CBDC:

- As a WCBDC would be accessible universally and 24x7x365, its users would make transactions when financial markets and central banks are usually closed. One consequence could be the development of an intraday market for WCBDC, in line with the trend toward real-time payments (Pfister, 2018);

- The issuance of a RCBDC could put a floor - possibly at zero if the RCBDC is not remunerated - to bank deposit rates. In the case of Sweden, Juks (2018) assesses that the increase in the cost of bank resources could amount to between 0 and 22 basis points, depending on the level of the policy rate and on the spread between this rate and the e-krona rate, with a possible null pass-through in case of a negative policy rate. In order to avoid putting too much pressure on bank intermediation, the central bank could choose, as the Riksbank did for the e-krona (Sveriges Riksbank, 2017 et 2018), not to remunerate the RCBDC initially. In any case, this remuneration should be set below or at the same level as that of the WCBDC if the latter is also issued, in order to avoid creating arbitrage opportunities for WCBDC holders. It should even be set strictly below the interest rate on the WCBDC if the central bank wishes to separate the circulation of the two forms of CBDC. Whereas the impact on the cost of bank resources could be non-negligible, that on banks' net resources should be nil. Indeed, as indicated in the section on the characteristics of a CBDC, part of its issuance would substitute for outside money. Beyond that, the loss of bank deposits of the public would be offset by a decrease in reserves (in the present case of a structural liquidity excess, which presently prevails in most developed economies, with moreover a negative remuneration of excess reserves in the euro area) and/or an increase in central bank refinancing (in the more traditional 
case of a structural liquidity deficit). Furthermore, the loss of bank deposits could be limited: Juks (2018) assesses that a little less than 5\% of the bank deposits of the public would be transferred towards the e-krona. Finally, if the distribution of the RCBCD is intermediated, as is likely (see second section), banks would not lose access to the information on their customers' accounts, except if their supply is not competitive in comparison with that of payment service providers.

\section{Monetary policy}

The main objective of monetary policy is price stability. Starting from a situation in which inflation would be below target, it could transitorily be more difficult to achieve as a result of the positive supply shock following the issuance of a CBDC (see above), unless the demand shock created by RCBDC issuance is large enough to offset the disinflationary impact of the supply shock. The consequences for the implementation of monetary policy and for its transmission mechanism could be both more important and above all permanent.

As regards the implementation of monetary policy, CBDC issuance could:

- Result in a more volatile and thus more difficultly forecastable demand for central bank money, in particular as a result of the demand from non-residents and in periods of financial crisis;

- Offer an opportunity to widen access to central bank money to payment service providers for the WCBDC and the RCBDC, and to financial institutions beyond just banks for the WCBDC;

- Lead to the adoption of a real-time monetary policy, echoing the development of an intraday market for WCBDC, and more generally the broadening of real-time payments (Pfister, 2018).

An important issue for monetary policy implementation would relate to the CBDC rate of interest. As the CBDC would be part of the monetary base, its remuneration should be compared to those of the other components: banknotes, which are not remunerated, and reserves which, in the Eurosystem, are remunerated at the policy rate - the main refinancing operations rate - for required reserves, and the deposit facility rate for excess reserves. ${ }^{5}$ As regards the WCBDC, two possibilities can be envisaged:

- Remunerating it at the same interest rate as required reserves. This choice would have the advantage of being neutral, insofar as institutions wishing to choose between holding the WCBDC and reserves would not be influenced by interest rate considerations;

- Remunerating it at a rate slightly below that on required reserves (e.g. the rate on excess reserves, i.e. the deposit facility rate in the case of the ECB). This choice would make it possible to take into account the services provided by the WCBDC, which would be higher than those provided by reserves. The drawback would be that the valuation of the spread may be difficult and time-variable, thus offering

\footnotetext{
${ }^{5}$ Since 2008 , the Fed has also been able to remunerate reserves at two different rates but has constantly set them at the same level (Drumetz et al., 2015).
} 
institutions arbitrage opportunities, and potentially frequent conversions between the WCBDC and reserves.

As regards the RCBDC, it could not be remunerated at a higher rate than the WCBDC rate. Banks would otherwise convert all their WCBDC into RCBDC, while bank deposits would be converted into RCBDC or remunerated at least at the RCBDC rate. .

Overall, the interest rate on required reserves could be used to remunerate the WCBDC, for reasons of simplicity and efficiency, even if this might lead to a rapid substitution of WCBDC for reserves. A rate below or equal to the rate on excess reserves could be applied to the RCBDC, in order to dissuade institutions from holding the RCBDC and thus keep it for the public. Finally, it is sometimes recommended to use the RCBDC rate of interest as a policy instrument so as to influence bank deposit rates directly and independently from a change in the policy rate, in particular in in the case of strains on bank liquidity (Nissan et al., 2018). However, such a possibility, which would be analogous to the setting of regulated rates in France, would create distortions in the transmission mechanism and in portfolio choices (Candus et al., 2017). Furthermore, seeking to increase the spread between market rates and bank deposit rates could give the impression that the central bank has private negative information on the banking sector, and trigger a bank run, instead of reducing its risk.

As regards the transmission mechanism, the way it is affected would depend to a large extent, if an RCBDC is issued, on whether it is remunerated or not:

- If the RCBDC is remunerated in a non-symbolic manner, the interest channel should be strengthened and the pass-through of its changes to bank deposit rates reach one for one, as long as the policy rate is positive (Armelius et al., 2018). The exchange rate channel should also be strengthened if, as indicated above, the major international investors invest in assets that are denominated in RCBDC, or the interest rate on these assets is referenced on that of the RCBDC. As regards the credit channel, Armelius et al. (2018) assess that it could be weakened if banks reduce their supply of loans as a result of a lower income on the management of deposits. Moreover, Andolfatto (2018) is of the opinion that bank deposits could increase if competition with the RCBDC forces banks to increase deposit rates. Nevertheless, if competition for the distribution of credit is weak, the pass-through of the rise in banks' cost of resources would be easier and the negative impact on the credit outstanding reduced. Finally, unless currency is eliminated or an exchange rate for it is set (Pfister and Valla, 2017), which could be done independently of the issuance of a RCBDC, the latter should lead to a reduction in the effective lower bound;

- If the RCBDC is not remunerated, this effective lower bound would effectively be raised to zero, whereas the various costs related to the holding of cash currently make it possible to set slightly negative interest rates (Nessén et al. 2018). Furthermore, the zero lower bound would not apply only to short-term maturities since future short-term rates would not be below zero either and the services provided by a RCBDC should be comparable to that provided by government securities (Armelius et al., 2018). It follows that government securities could no 
longer be remunerated at negative interest rates, and thus that the effectiveness of government securities purchases by the central bank, which acts on expected shortterm interest rates and on term premia which represent services provided, would be jeopardized, unless regulatory constraints support the holding of these securities (Armelius et al., 2018). Lastly, even in the latter case, negative interest rates could not extend to other categories of issuers, unless they also benefit from regulatory constraints, which would diminish the relative advantage granted to government securities.

Overall, RCBDC remuneration could create a trade-off between the effectiveness of monetary policy and the cost of bank intermediation. In any case, whether the RCBDC is remunerated or not, the following inequalities would be respected:

Interest rate on required reserves $\geq$ Interest rate on $\mathrm{WCBDC} \geq$ Interest rate on RCBDC $\geq$ Effective lower bound

If the central bank wishes to avoid that financial institutions hold a RCBDC rather than reserves of WCBDC, one would also need:

Interest rate on $\mathrm{WCBDC} \geq$ Interest rate on excess reserves $\geq$ Interest rate on RCBDC, with the second case of inequality applying when rates are set at zero.

\section{Financial stability}

Concerns have been voiced (Carney, 2016; Bank for International Settlements, 2018) that RCBDC issuance may facilitate bank runs and exacerbate liquidity strains. It might even lead, in case of recurrent financial crises, to an overall negative impact on economic growth (Armelius et al., 2018). However, if the structural liquidity deficit is high enough (see above), having the central bank as the most important depositor should on the contrary reassure the public. Indeed, the central bank is unlikely to withdraw its deposits precipitously since it is not submitted to a liquidity constraint. Furthermore, the risk of bank runs taking place just on the basis of rumours should diminish, since the central bank can be expected to have better access to information than the public. Also, a factor supporting financial stability would be that the central bank would be rapidly informed of runs out of bank deposits into RCBDC, which would reduce the risk of contagion (Kumhof and Noone, 2018). Finally, supposing, however, that runs do become frequent, one cannot exclude that this development might render banks more prudent (Engert and Fung, 2019).

However, the fact that the central bank is better informed should make it more difficult for it to refuse its support to an institution suffering from a run. Thus, the risk is that the central bank may act too often as a lender of last resort to individual institutions. This risk would be an additional reason, on top of existing ones, to limit moral hazard consequences inherent in the conduct of lending of last resort operations, by making access to them more rule-based (Pfister and Valla, 2017).

Besides, the main motivation for supplying a CBDC, i.e. to allow all economic agents to have a perfectly safe digitalised means of payment at their disposal, and thus to preserve economic activity in all circumstances, would still be at play, particularly in times of crisis. This argument is 
already valid, as far as the no-digitalised aspect is concerned regarding cash. Even if runs became more frequent, their negative consequences for economic activity would thus be lessened.

\section{Conclusion}

Issuing a CBDC could be beneficial to the economy. However, it would raise some rather thorny issues, notably regarding the respective roles of the central bank and the private sector in the supply of money. This would particularly be the case for a RCBDC, while a WCBDC might meet the expectations of strongly internationalised financial institutions. The choice could thus be between not issuing a CBDC and issuing only the wholesale one. In countries where the dwindling use of cash would lead to the emergence of a demand for a digital means of settlement from the public, issuing a RCBDC would also be a possibility. 


\section{REFERENCES}

Andolfatto D. (2018), "Assessing the Impact of Central Bank Digital Currency on Private Banks", Federal Reserve Bank of St. Louis, Working Paper 2018-026C, https://s3.amazonaws.com/real.stlouisfed.org/wp/2018/2018-026.pdf.

Armelius H., Boel P., Claussen C. A., Nessén M. (2018), "The e-krona and the macroeconomy", Sveriges Riksbank Economic Review, 2018-3, 43-65, https://www.riksbank.se/globalassets/media/rapporter/pov/engelska/2018/economic-review3-2018.pdf\#page $=43$.

Bank for international settlements (2018), Central bank digital currencies, Report of the Committee on Payments and Market Infrastructures and the Markets Committee, March, https://www.bis.org/cpmi/publ/d174.htm.

Banque de France (2018), Rapport annuel de l'Observatoire de l'inclusion bancaire 2018, June, https://publications.banque-france.fr/sites/default/files/medias/documents/oib2018 web signets.pdf.

Barontini C., Holden H. (2019), "Proceeding with caution - a survey on central bank digital currency", BIS Papers, 101, https://www.bis.org/publ/bppdf/bispap101.pdf.

Berentsen A., Schär F. (2018), "The Case for Central Bank Electronic Money and the Non-case for Central Bank Cryptocurrencies", Federal Reserve Bank of St. Louis Review, 100(2), 97-106, https://research.stlouisfed.org/publications/review/2018/02/13/the-case-for-central-bankelectronic-money-and-the-non-case-for-central-bank-cryptocurrencies.

Candus E., Pfister C., Sédillot F. (2017), "Where do French people invest their savings?”, 2017, Banque de France Quarterly Selection of Articles, 48, 5-21, https://publications.banquefrance.fr/sites/default/files/medias/documents/quarterly-selection-of-articles-no-48.pdf.

Drumetz F., Pfister C., Sahuc J.-G. (2015), Politique monétaire, second edition, de Boeck.

Engert W., Fung B. S. C. (2019), "Motivations and implications of a Central Bank Digital Currency", in Suerf, Do We Need Central Bank Digital Currency? Economics, Technology and Institutions, edited by Ernst Gnan and Donato Masciandaro, https://www.suerf.org/studies/7025/do-weneed-central-bank-digital-currency-economics-technology-and-institutions, 56-71.

Federal Reserve System (2019), Federal Reserve Actions to Support Interbank Settlement of Faster Payments, 5 August, https://www.federalreserve.gov/newsevents/pressreleases/files/other20190805a1.pdf.

Fung B. S. C., Halaburda H. (2016), "Central Bank Digital Currencies: A Framework for Assessing Why and How", Bank of Canada, Discussion Paper 2016-22, https://www.researchgate.net/publication/318555671 Central Bank Digital Currencies A Fra mework for Assessing Why and How.

Ingves S. (2018), "The e-krona and the payments of the future", 6 November, https://www.riksbank.se/globalassets/media/tal/engelska/ingves/2018/the-e-krona-and-thepayments-of-the-future.pdf.

Juks R. (2018), "When a central bank digital currency meets private money", Sveriges Riksbank Economic Review, 2018-3, 79-99, http://prod-upp-image-read.ft.com/c080e86a-966c-11e9-8cfb30c211dcd229. 
Kumhof M., Noone C. (2018), "Central bank digital currencies - design principles and balance sheet implications", Bank of England, Staff Discussion Paper 725, https://www.bankofengland.co.uk/working-paper/2018/central-bank-digital-currencies--design-principles-and-balance-sheet-implications.

Libra Association (2019), White Paper, 18 June, https://libra.org/en-US/wpcontent/uploads/sites/23/2019/06/LibraWhitePaper_en US.pdf.

Morgan J.P. (2019), J.P. Morgan Creates Digital Coin for Payments, 14 February, https://www.jpmorgan.com/global/news/.

Nessén M., Sellin P., Sommar P. § (2018), “The Implications of an e-krona for the Riksbank’s operational framework for implementing monetary policy", Sveriges Riksbank Economic Review, 2018 3, 29 42,-https://www.riksbank.se/globalassets/media/rapporter/pov/arti klar/engelska/2018/181105/20183-the-implications-of-an-e-krona-for-the-riksbanks-operational -framework-for-implementing-monetary-policy.pdf.

Niepelt D. (2019), "Reserves for All? Central Bank Digital Currency, Deposits, and their (Non)Equivalence", International Journal of Central Banking, forthcoming.

Pfister C. (2017), "Monetary Policy and Digital Currencies: Much Ado about Nothing?", Working Paper, 642, Banque de France, https://publications.banque-france.fr/sites/default/files/ medias/documents/dt-642.pdf.

Pfister C. (2018), "(Real-)Time Is Money", Working Paper, 675, Banque de France, https://publications.banque-france.fr/sites/default/files/medias/documents/wp675.pdf.

Pfister C., Valla N. (2017), “New Normal' or 'New Orthodoxy'? Elements of a Central Banking Framework for the After-Crisis", 2018, Working Paper 680, Banque de France, https://publications.banque-france.fr/sites/default/files/medias/documents/wp680.pdf.

Schmiedel H., Gergana K., Ruttenberg W. (2012), “The Social and Private Costs of Retail Payment Instruments - A European Perspective", European Central Bank, Occasional Paper Series, 137, https://www.ecb.europa.eu/pub/pdf/scpops/ecbocp137.pdf?33f4f6bcb83613df99d d634b89e2c8a0.

Segendorf B. (2018), "How many e-krona are needed for payments?", Sveriges Riksbank Economic Review, 2018:3, 66-78, https://www.riksbank.se/globalassets/media/rapporter/pov/arti klar/engelska/2018/181105/20183-how-many-e-krona-are-needed-for-payments.pdf.

Skingsley C. (2016), "Should the Riksbank issue e-krona?", 16 November, https://www.riksbank.se/globalassets/media/tal/svenska/skingsley/2016/tal skingsley 161116 eng.pdf.

Sveriges Riksbank (2017), The Riksbank's e-krona project - Report 1, September, https://www.riksbank.se/globalassets/media/rapporter/e-krona/2017/rapport ekrona uppdate $\underline{\text { rad } 170920 \text { eng.pdf. }}$

Sveriges Riksbank (2018), The Riksbank's e-krona project - Report 2, October, https://www.riksbank.se/globalassets/media/rapporter/e-krona/2018/the-riksbanks-e-kronaproject-report-2.pdf. 